\title{
A BRIEF ANALYSIS OF THE ENLARGEMENT PROCESS FOR THE WESTERN BALKANS STATES. SYNTHETIC EVALUATION OF THE INTEGRATION PATH WITHIN THE COMPETITIVENESS POLICY
}

\author{
Monica Ioana BURCĂ-VOICU, PhD \\ Faculty of European Studies, Babeș-Bolyai University Cluj-Napoca, Romania \\ monica.voicu@ubbcluj.ro \\ Mihaela Adriana OPRESCU, PhD \\ Faculty of European Studies, Babeș-Bolyai University Cluj-Napoca, Romania \\ mihaela.oprescu@ubbcluj.ro
}

\begin{abstract}
In the process of negotiations with the EU candidate countries, one of the acquis chapters related to the sectoral issues, is the competitiveness policy on the closure of which depends to a large extent the completion of negotiations. The Western Balkans region is at the same time a strategic priority for the European Union as well as a real challenge in terms of economic convergence due to the criteria that continue to lag behind the development and compliance with the aquis communautaire compared to the already member states.

The aim of the present research is to present the EU legal framework related to the competitiveness sector trying to capture the challenges met on the path to integration in this regard, taking also into account the national economic and legal context of the Western Balkans countries (Albania, Bosnia and Herzegovina, Croatia, North Macedonia, Montenegro and Serbia). The present analysis starts methodologically with a brief presentation of the general legislative framework with reference to the competing elements to be fulfilled in the enlargement process of the European Union and contextualized upon the economic realities of the Western Balkans states trying to capture at the same time the fulfilment level of the main criteria to be met in accordance with a free market economy and a strong competitive environment.
\end{abstract}

Keywords: Western Balkans countries, EU Single Market, economic integration, competitiveness.

\section{Introduction}

European economic integration is a complex process consisting in the formalinstitutionalized consolidation of interdependencies between all spheres of national and international economic life of the member states. 
According to the provisions of art. 3 (3) of the Treaty on European Union, the internal market acts for the sustainable development of Europe, based on balanced economic growth and price stability, a highly competitive social market economy, which aims at full employment and social progress, as well as a high level of protection and improvement of the quality of the environment.

The internal market has effects on both citizens and the business environment in terms of better employment and more business opportunities (Dobre, 2010, p.65). The advantages of achieving economic integration and consolidating an extensive internal market allow companies to achieve growth, enter other national markets and specialize in production. This in turn allows European companies to compete on the world economic stage (Foster, 2018, p.281).

We note, therefore, that the internal market is not an objective, but a means to economic and social progress. The evolution of the notion of common market, starting with the Single European Act (SEA), towards the new concept of internal market is the result of the efforts to assimilate the European market to a national market without any barriers. The Single European Act, signed on 28 February 1986 and entered into force on 1 July 1987, highlighted the shortcomings of the common market and drew up a program for its transformation into a single market by the end of 1992. According to Art. 8a of the EEC Treaty (text introduced by Article 13 of the Single European Act), „,The Community shall adopt measures with the aim of progressively creating the internal market by 31 December 1992. The internal market shall consist of a market without internal frontiers, in whose territory the free movement of goods, persons, services and capital will be ensured in accordance with the provisions of this Treaty."

Such assimilation will present a new configuration. In fact, until the Single European Act, the Community acted mainly by removing obstacles to trade in various forms, while since the assertion of this new legal institution - the internal market - the Community institutions have sought to support and strengthen a process convergence between national legal orders by establishing Community policies that allow for better economic integration. In other words, the conceptual evolution of the common market notion towards that of the internal market is in reality only a reflection of the evolution of the global project of European integration and, in particular, from an economic point of view (Boutayeb, 2009, p.21).

The internal market is the place where supply and demand meet, so no restrictions or conditions should be imposed for the entry of a product into the national market of a Member 
State. These limitations or conditions may be represented by customs duties or the introduction of quotas and, in general, measures that may affect the free movement of goods, persons, services and capital, in a manner that restricts the economic activity (Popa Nistorescu, 2007, p.80).

The internal market is certainly one of the most important achievements of the European Union, due to the fact that restrictions on trade and free competition have gradually been removed between Member States, to the benefit of citizens and the business environment, to whom many business opportunities have opened up.

Moreover, the principle of free competition is the cornerstone on which the functioning of the internal market is based. However, European law does not adhere to the theory of "competitioncondition", according to which competition should be seen as an end in itself, which prevails over any other interests, instead embracing the theory of "competition-means", conceived as a means to achieve other economic or political objectives, respectively, as an essential and privileged instrument of economic progress, which, however, can be sacrificed when this is demanded by a higher interest (Oprescu, Ciceo, 2017, p.406). In other words, competition policy can only be conceived in an indissoluble link with other Union policies.

At the same time, we can say that competition policy is a lever for achieving the goal of integrating national markets, on the one hand, by sanctioning the behaviour of businesses and Member States that prevent, restrict or distort the competition in the internal market, and on the other hand, by encouraging trade between Member States.

In a brief presentation, the main objectives of the EU competition law are the following: to maintain openness and unify the internal market; to ensure economic efficiency in the marketplace; to grant the conditions of effective competition and competitiveness; to protect the consumers (Kaczorowska, 2011, p.773).

\section{Accession to the European Union}

According to art. 49 TEU, "Any European State which respects the values referred to in Article 2 and is committed to promoting them may apply to become a member of the Union". If until the 1995 accession wave, candidates had a relatively similar political and economic system, so that accession did not depend so much on the results of evaluations carried out by the Community bodies as on the concordant will of the Member States and the candidate country, after that time, more precisely, with the collapse of the communist bloc, we are witnessing a change of 
perspective (Gyula, 2018, p.51). Thus, the disintegration of the communist has created the opportunity for expressing the desires of integration for the former socialist states, whose politicaleconomic systems raised a lot of compatibility problems in relation with the existing ones in the EC member states and implicitly with the Community settlements.

EU accession has therefore become a long and complicated process of adjusting all the internal areas of the candidate countries to EU principles, values and standards. In order to guide the candidate countries on compliance path with the requirements of the accession reforms, the Copenhagen European Council of 21-22 June 1993 established mandatory accession criteria, as follows (Dubouis, Blumann, 2012, p. 745):

a. Geographical criterion (the state must be located on the European continent)

b. The political criterion (the rule of law, the existence of stable democratic institutions, the rule of law, human rights and the protection of minorities).

c. Economic criterion (functional market economy, able to cope with competitive pressures and market forces within the EU).

d. Ability to fulfil the obligations arising from the status of Member State (taking over the objectives of political, economic and monetary union; taking over the acquis communautaire).

To these criteria has been added the additional requirement introduced at the 1995 Madrid European Council, namely for the administration and the judiciary to be able to have the capacity to apply the acquis communautaire.

The Western Balkans states will also have to comply besides the general already mentioned criteria with other two supplementary groups of requirements formulated by the European Council of 1997 and 1999 (Uvalic, 2010, pp.53-86):

- Western Balkans countries had to demonstrate their willingness to implement regional cooperation with neighbouring states, by actively participating in initiatives on regional cooperation and regional projects in various areas, in order to resolve common problems of mutual concern; and ${ }^{1}$

- Western Balkans countries had fulfil all their international obligations, including collaboration with the International Criminal Tribunal for the former Yugoslavia (ICTY) in The Hague, the Dayton Peace Accords, the UN Security Council Resolution 1244, and so forth.

\footnotetext{
${ }^{1}$ See for more informations Commission of the European Communities (1997), Conclusions of the General Affairs Council of 29 April, Brussels. and Commission of the European Communities (1999), Conclusions of the General Affairs Council of 21/22 June, Brussels
} 
Taking a look at the current situation of the Western Balkan states, we can see their inhomogeneous status in terms of the EU accession process. The most advanced in the accession process are Montenegro and Serbia, for which accession negotiations are already under way (from 2012 for Montenegro and 2014 for Serbia). Therefore, these two countries are at a stage where they need to adapt their legislation and administrative capacity to allow the negotiations to be closed. Secondary, in the accession process we can name Northern Macedonia (candidate since 2005) and Albania (candidate since 2014). On 24 March 2020, ministers for European affairs gave their political agreement to the opening of accession negotiations with Albania and the Republic of North Macedonia (European Council, 2020). Bosnia and Herzegovina ${ }^{2}$ and Kosovo ${ }^{3}$ are far behind, with only potential candidate status. It should be noted that, despite opposition from some Member States to the further enlargement of the EU and certain obstacles in the candidate countries, accession remains an important political goal for both the EU and all the countries of the Western Balkans.

Although none of the countries in the Western Balkans currently meet the accession criteria, the region has made great strides since the late 1990s. Overall, significant progress is undeniable both in terms of reforms and overcoming the devastating legacy of wars and conflicts.

Regarding the trade conditions with the European Union, since 2000 preferential agreements are in place at the moment, until at the end of this year, conditions that are eliminating (for almost all the trade sectors with a few exceptions) the custom duties and the quantitative restrictions and quotas. Even though those preferential conditions will expire at the end of this year, we are at the moment expecting the decision of the European Parliament and Council in connection with a potential extension until 2025 of this preferential exchange agreement (EC, 2020).

\footnotetext{
${ }^{2}$ Bosnia and Herzegovina's application for EU membership was submitted on 15 February 2016.

${ }^{3}$ The Stabilization and Association Agreement entered into force in April 2016.
} 


\section{Brief assessment of the level of competitiveness for the Western Balkans States - facts} and figures

Competition policy is essential in the economic environment of the European Union due to the fact that the main way to achieve economic objectives is only throughout competitive markets and also because internal market principles can fail or generate unsatisfactory results if restrictive practices at national level would create barriers to competition between Member States (Pelkmans, 2003).

The present insight into the state of the competitiveness frameworks for expressing the achieved level and key determinants from the perspective of the proposed research topic will try to identify significant analytical patterns and influential factors determining the current state of the economic competitiveness of the Western Balkan countries (Albania, Bosnia and Herzegovina, Croatia, Macedonia, Montenegro and Serbia).

Therefore we intend to evaluate if the Western Balkan countries are still lagging behind the European Union member states in relation with the competitiveness level related to innovation and ability to fully compete within the EU Single Market or there have been made significant progress in increasing performance and competitive capacity.

Innovation is one of the key factors to be boosted in order for the national economy to be able to provide/supply value added products reflecting this way the ability to perform within a highly competitive European market. This fact is of a real importance for de investigated countries taking into consideration the fact that the Western Balkans countries are dependent on their export to the EU which at the moment accounts for more the $70 \%$ of the total Western Balkans countries exports to the Single European Market (representing only $1.4 \%$ of the total EU trade). What is really important is to underline the idea that due to the fact that in 2000 the EU has granted autonomous trade preference to all the Western Balkans, there has been a rather rapid growth of the trade with the EU partners by almost 130\%, summing up approximately EUR 55 billion in 2019, the Western Balkan countries increasing their exports to the EU by 207\%. (EC, 2020).

The Global Competitiveness Report 2019 indicates some key results in relation with the current status of the main characteristics defining the competitiveness index of the Western Balkans states, elements related to aspects such as: institutional performance, infrastructure level of development, ICT adoption, macroeconomic stability, health, skills, product markets, labour markets, financial systems, market size, business dynamism and innovation capability. 
Table 1. Country Ranking based on the Global Competitiveness Report 2019

\begin{tabular}{|c|c|c|c|c|c|c|}
\hline $\begin{array}{l}\text { Country } \\
\text { Rank /141 }\end{array}$ & $\begin{array}{l}\text { Albania } \\
87 s t / 141\end{array}$ & $\begin{array}{l}\text { Bosnia and } \\
\text { Herzegovina, } \\
92^{\text {nd }} / 141\end{array}$ & $\begin{array}{l}\text { Croatia } \\
63^{\text {rd }} / 141\end{array}$ & $\begin{array}{l}\text { Macedonia } \\
82^{\text {nd }} / 141\end{array}$ & $\begin{array}{l}\text { Montenegro } \\
73^{\text {rd }} / 141\end{array}$ & $\begin{array}{c}\text { Serbia } \\
72^{\text {nd }} / 141\end{array}$ \\
\hline institutional performance & 76 & 114 & 77 & 84 & 53 & 75 \\
\hline $\begin{array}{l}\text { infrastructure level of } \\
\text { development }\end{array}$ & 98 & 84 & 32 & 75 & 83 & 51 \\
\hline ICT adoption & 75 & 80 & 60 & 70 & 57 & 77 \\
\hline macroeconomic stability & 104 & 64 & 42 & 82 & 104 & 64 \\
\hline health & 46 & 73 & 47 & 64 & 65 & 76 \\
\hline skills & 50 & 82 & 69 & 83 & 53 & 55 \\
\hline product market & 75 & 108 & 86 & 110 & 42 & 73 \\
\hline domestic competition & 120 & 124 & 108 & 126 & 52 & 98 \\
\hline trade openness & 22 & 74 & 57 & 81 & 38 & 51 \\
\hline labour market & 38 & 107 & 94 & 82 & 26 & 54 \\
\hline financial systems & 102 & 80 & 63 & 83 & 44 & 82 \\
\hline market size & 111 & 101 & 78 & 109 & 134 & 74 \\
\hline business dynamism & 63 & 117 & 101 & 65 & 50 & 54 \\
\hline and innovation capability & 110 & 117 & 73 & 97 & 69 & 59 \\
\hline
\end{tabular}

Source: WEF, (2019) The Global Competitiveness Report 2019, Editor Professor Klaus Schwab, Retrieved from http://www3.weforum.org/docs/WEF TheGlobalCompetitivenessReport2019.pdf

The table shows different stages of development in relation with the proposed criteria, the Western Balkan countries performing uneven as it can be seen, with quite large variations in a comparative analysis between them, Croatia reaching the best position ranking $63^{\text {rd }}$ and surpassing the other analyzed states by 9 and even 29 positions in the total structure of the rank. We can identify the fact that in terms of the trade openness Albania and Montenegro are holding positions that denote a real openness towards transaction that are embracing the identified opportunities within the global markets. Moreover, we can underline here also the fact that in relation with the 
last criteria, the innovation capability, Serbia is the country that performs best in this respect among the states analyzed within this research.

In 2018 Global Competitiveness Report, has indicated that the Western Balkans countries have score out of 100 points the following performing results: Bosnia and Herzegovina scored 54.73 points, Macedonia 57.33 points, Albania 57.61 points, Montenegro 60.82 points, Serbia 60.85 points, Croatia 61.94 points. (Trading Economics, 2018)

Based on the data provided by the European Commission Reports (EC, 2019, 2020) and also previously reflected by us in the Global Competitiveness Report 2019, in concern with the Western Balkans state of development toward the accession process we identified the fact that in general there are problems related to issues such as: a slow development of the institutional and regulatory framework and especially in concern with the secondary legislation implementation; the need to speed up the implementation of legislation on property rights and intellectual property as guarantors of an active and dynamic economic environment and fair competition; we notice significant progress in the legislative framework, being in some states respected, in Montenegro and Serbia to a large extent, in accordance with the acquis of the European Union, the institutional legal rules allowing to grant state aid only if restrictive conditions are to be met for the purpose of preventing distortions of competitive environment (as a negative example, in the case of Albania, the operational independence of the national authority with competences in the application of the competition policy has not yet been ensured, controls in this respect being still too low).

As for economic convergence, apart from the controversial adoption of the single European currency, Montenegro's indicators exhibit imbalances in areas such as unemployment and public debt (Corpădean, 2018).

We can strongly state that today's economic realities hinder the process of economic integration of the Western Balkans states, due to the increasing operational difficulties of the economic agents, the contraction of trade transactions with the European partner states to which they are interdependent, increasing unemployment rates and the deepening of the problems generated by the already existing structural difficulties. Moreover, we can mention here the real struggles existing in the current context of the harsh economic realities to reduce the current gaps in terms of the economic competitiveness as compared to the context of the European Internal Market. 
Based on the presented facts we can say that it is imperative for the Western Balkans states to sustain the economic development of the strategic domains related to the competitiveness of the private sector as the main engine for strengthening economic processes with a high emphasis on areas that must stimulate innovation as a strong point in increasing the competitive capacity of companies within the Internal Single Market.

At the same time, we consider that it is absolutely necessary to concentrate investments in those areas that register development gaps compared to the level of EU member states, and which must also be focused on the fundamental principles and values of the European Union as promoters of credibility and also assuming the basic principles of the single market.

\section{Conclusions}

With a view to accession, it is imperative for the Western Balkans states to reform key areas, in particular the rule of law, competitiveness, regional cooperation and reconciliation. It is noted that there are still important bilateral disputes between the countries in the region, in respect of which a solution must be found, mandatory before the accession, as the European Union cannot afford to take over these disputes, assuming the instability and uncertainty of such a context.

Moreover, essential reforms in the private sector are needed so that the Western Balkans countries can sustain the functioning of market economy basic principles capable of coping with competitive pressure and market forces within the Union.

As previously presented, we identified within this research the imperious need for deepening the reform process for several areas of economic interest which are currently undergoing noting also the fact that all Western Balkans countries are having robust export figures as a key indicator of international competitiveness.

\section{References}

1. Boutayeb, Chahira (2009), Droit matériel de l'Union européenne. Libertés de mouvement, espace de concurrence et intérét général, Paris: L.G.D.J.

2. Commission of the European Communities (1997), Conclusions of the General Affairs Council of 29 April, Brussels.

3. Commission of the European Communities (1999), Conclusions of the General Affairs Council of 21/22 June, Brussels 
4. Corpădean, Adrian-Gabriel (2018), Assessments And Prospects For The Integration Of The West Balkans. The Case Of Montenegro, in On-Line Journal Modelling The New Europe, Issue No. 25/2018, pp. 87-105, Retreived at: http://neweurope.centre.ubbcluj.ro/wpcontent/uploads/2018/04/ASSESSMENTS-AND-PROSPECTS-FOR-THE-INTEGRATION-

\section{OF-THE-WEST-BALKANS.-THE-CASE-OF-MONTENEGRO.pdf}

5. Dobre, Adrian (2010), Politica comercială comună a Uniunii Europene, Bucureşti: Universul Juridic

6. Dubouis, Louis; Blumann, Claude (2012), Droit materiel de l'Union européenne, Paris: Montchrestien,

7. EC, (2020), 2020 Enlargement Package and An Economic and Investment Plan for the Western Balkans, Retrieved from: $\underline{\text { https://ec.europa.eu/neighbourhood- }}$ enlargement/countries/package en

8. EC, (2020), EU-Western Balkans: Trade in goods, Retrieved from: https://ec.europa.eu/trade/policy/countries-and-regions/regions/western-balkans/

9. Fabian, Gyula (2018), Drept instituţional al Uniunii Europene, Bucureşti: Ed. Hamangiu 10. Foster, Nigel (2018), EU law, Oxford University Press

11. Kaczorowska, Alina (2011), European Union Law, second edition, New York: Routledge 12. Oprescu, Mihaela; Ciceo, Georgiana (2017), Politica în domeniul concurenţei, în Nicolae Păun (coord), Uniunea Europeană în contextul unei lumi în schimbare. Fundamente istorice, valori, instituţii, politici, Bucureşti: Ed. Academiei Române

13. Pelkmans, Jacques (2003), Integrare Europeană. Metode și Analiză Economicăa ediția a doua, București: Institutul European din România

14. Popa Nistorescu, Cristina (2007), Libera circulaţie a mărfurilor şi importanţa sa pentru magistratul naţional, in Revista de Ştiinţe juridice nr. 3-2007

15. Trading Economics, (2018), Global Competitiveness Report, WEF, Retrieved at https://tradingeconomics.com/search.aspx?q=Competitiveness\%20index

16. Uvalic, Milica (2010), in Integrating the Western Balkans into the European Union: How useful are the EU economic accession criteria?, in Western Balkans' Accession to the European Union. Political and Economic Challenges, Editors Božidar Cerović and Milica Uvalić, Čugura Print Editors, Belgrad, from: https://www.researchgate.net/profile/Milica Uvalic/publication/303919800 Integrating the We 
stern_Balkans into the European_Union_How useful_are the EU economic accession_criter ia/links/575d93ef08aec91374aef5d2/Integrating-the-Western-Balkans-into-the-European-UnionHow-useful-are-the-EU-economic-accession-criteria.pdf

17. WEF, (2019), The Global Competitiveness Report 2019, Editor Professor Klaus Schwab, Retrieved from:

http://www3.weforum.org/docs/WEF TheGlobalCompetitivenessReport2019.pdf 